\author{
EISSN:2706-7920 ISSN: 2077- 4435 \\ DOI: $10.36632 / \mathrm{csi} / 2021.10 .2 .30$ \\ Journal homepage: www.curresweb.com \\ Pages: 324-334
}

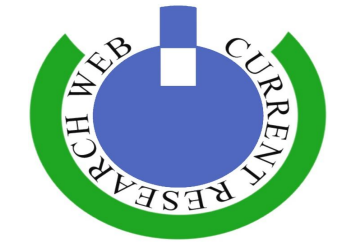

\title{
Evaluation of a high nutrition value gluten free pan bread prepared
}

\author{
Fatma M. I. Shahin and Manal S. Helal
}

\author{
Food Technology Research Institute, Agricultural Research Centre, Giza, Egypt
}

Received: 10 May $2021 \quad$ Accepted: 15 June $2021 \quad$ Published: 30 June 2021

\begin{abstract}
Consumer demands for healthy and convenient diet has led to development of a huge room for functional food ingredients. The objective of the present study undertaking to investigate the nutritional value, sensory characteristics of gluten free pan bread prepared red kidney beans, rice, sorghum, cassava, psyllium and doum fruit powder which is suitable to be incorporated into celiac disease diets. This investigation was carried out to study the possibility of utilization doum powders to improve the nutrition value in gluten free pan bread. Four formula levels of substitution 5\% doum formula (1), $10 \%$ doum formula (2), $15 \%$ doum formula (3) and $20 \%$ doum formula (4) were used. Physico-chemical and sensorial analysis of different raw materials and formulas were done. The obtained results revealed that red kidney bean had the highest contents of protein (26.39) and cassava had the highest contents of carbohydrates $92.16 \%$. The highest values of fat and fiber were noticed in the psyllium flour while ash content was in the doum powder. The protein, ash and crude fiber contents in $20 \%$ doum substituted (formula (4) were increased by $12.08,36.46$ and $167.11 \%$ respectively in relative to the control (2) On the other hand, total carbohydrates content decreased in the same formula by $6.50 \%$. It was noticed that increase the doum levels in the formulation, significantly $(\mathrm{P} \leq 0.05)$ increased $\mathrm{K}, \mathrm{Ca}, \mathrm{Na}, \mathrm{Mg}, \mathrm{Fe}$ and $\mathrm{Zn}$ content in pan bread formulas compared to that of control. Specific volume was decreased in $20 \%$ doum $\left(3.68 \mathrm{~cm}^{3} / \mathrm{g}\right)$ in relative to the control sample $\left(4.05 \mathrm{~cm}^{3} / \mathrm{g}\right)$. It was also observed that with increasing the doum powder levels in the pan bread formula, hardness and chewiness were increased. Meanwhile, resilience, cohesiveness and springiness were decreased with increasing the doum levels in the pan bread formulae-Substitution of doum powder up to $10 \%$ was acceptable by panelists. It could be concluded that consuming doum powder gluten free pan bread could provide children with part of their daily requirements of protein, fiber, calcium, iron and zinc in celiac diets.
\end{abstract}

Keywords: red kidney, rice flour, doum, psyllium, cassava flour, pan bread

\section{Introduction}

Celiac disease (CD) is an autoimmune enteropathy caused by the ingestion of gluten containing grains in genetically susceptible individuals. The $\mathrm{CD}$ is one of the most common food induced disorders worldwide with an estimated mean prevalence of $1 \%$ of the total population (Lamacchia et al., 2014). New recent epidemiological data showed that celiac disease (CD) is a common disease in the world. It's now understood to affect as many as 1:266 people worldwide. However, its symptoms are common to many other conditions and can range in severity. CD is often overlooked or misdiagnosed. Consequently, individuals may remain undiagnosed and untreated for many years (Saturni et al., 2010).

Rice (Oryza sativais) is main staple food for many countries, providing $20 \%$ of the food energy supply in the world. Rice is characterized by low prolamin, hypoallergenic activity, insipid taste, low sodium and high digestible carbohydrate contents, which is suitable to be incorporated into celiac diets (Phimolsiripol et al., 2012). The most popular gluten free bread products are based on rice flour (Matos et al., 2014). 
Sorghum (Sorghum bicolor L.) is a cheap source of natural antioxidants to prevent the development of oxidative rancidity in edible oils and other lipid food systems (Dykes and Rooney, 2007).

The use of cassava (Manihot esculenta) flour in bread making is a convenient alternative for promoting the use of a local crop as well as reducing imports of wheat flour, promoting the production of high quality cassava flour, offering a gluten-free product and developing biofortified and fortified foods. Although the substitution level of cassava flour is limited, in some products, the incorporation of additives or flours from other crops improve the nutritional value and bread making quality of the baked foods (Aristizábal et al., 2017).

Red kidney beans (Phaseolus vulgaris L.) consider to be high in component like protein (possess essential amino acid) carbohydrates, dietary fiber, minerals and vitamins. Proteins are normally considered as the prominent macronutrient in red kidney beans (Boye et al., 2010). Its protein has the highest lysine content (about $5 \%$ ) and can be used for the fortification of cereal based products (Thapa, 2012).

Doum (Hyphaene thebaica L.) fruit is an excellent source of carbohydrate and fiber. Additionally, micronutrients such as vitamins (especially B vitamins) and minerals including $\mathrm{K}, \mathrm{Na}$, $\mathrm{Ca}, \mathrm{Mg}$, and $\mathrm{P}$ also help to regulate the biological process in body and impart health benefits (Admassu et al., 2013). Doum fruit has been used as an anti-hyperlipidemia drug (Sa'adah et al., 2017). According to Bayad (2016), the H. thebaica fruits have antimicrobial, antioxidant, antidiabetic, antihypertensive and hypolipidemic effects. Doum has nutritional and pharmacologic properties (Aboshora et al., 2017). It contained a high amount of amino acids such as valine, leucine and some non-essential amino acids such as alanine, aspartic acid, glutamic acid, glycine, serine and proline. It is also, very rich in minerals such as potassium $(\mathrm{K})$ and phosphorous $(\mathrm{P})$ (Abdel-Rahman 2011).

Psyllium and xanthan gum present similar rheological behaviours, as both are responsible for weak gelling properties (Haque et al., 1993). Psyllium had a similar behaviour to xanthan with respect to specific volume and weight loss (Belorio and Gómez, 2020). Psyllium (Plantago ovata) is a source of natural and concentrated soluble fiber derived from the husks of blonde psyllium seed. Husk is the outermost skin of the seed which is removed by a mechanical process. Total recovery of husk is around 25 to $26 \%$ from the seed. The psyllium husk contains $6.83 \%$ fiber, $0.94 \%$ protein, $4.07 \%$ ash and $84.98 \%$ total carbohydrates (Anjali and Renu, 2015). These properties allow its application in the food industry to carry out pysllium can be used as a substitute of gluten, fat or act as an emulsifier or a thickening agent (Zandonadi et al., 2009).

In commercial products, the use of psyllium is also prominent, similarly, as other hydrocolloids; psyllium is a natural fiber with important hydration and gel-forming properties (Belorio et al., 2020)

So, the present investigation aimed to assess the possibility of producing new modified formula of gluten free pan bread with high nutritive value.

The objectives of this study were to use:

1- Rice, cassava and sorghum (as a wheat replacer) as a source of carbohydrates and free gluten

2- Pysllium as a substitute for xanthan, acts as an emulsifier and thickening agent.

3- Red kidney bean as a source of protein, essential amino acid especially lysine.

4- Doum fruit powder as a rich source, minerals and as a functional ingredient

\section{Materials and Methods}

\subsection{Materials:}

Cassava tubers were obtained from Horticultural Res. Institute, Vegetables Department. Rice (Oryza Sativa L.), Psyllium, sorghum (Sorghum bicolor L.), and red kidney bean (Phaseolus vulgaris L.) were purchased from Field Crops Res. Institute, Agric. Res. Center, Giza. Egypt.

Doum fruit flakes (Hyphaene thebaica) were obtained from El Khateeb Company, Giza, Egypt. Instant active dry yeast, sodium chloride and corn oil were purchased from the local market, Cairo, Egypt. 


\subsection{Methods}

\subsubsection{Preparation of raw materials}

Red kidney bean were thermally treated seprestely for 30 minutes at $100 \mathrm{c}$ to be effective for improving the nutritional value and flavor according to the method described by McWatters, (1985).

Cassava tubers were washed, peeled and soaked in water for five days after the chipping operation. The water was changed every day (Tewe, 1983) to allow residual hydrocyanic acid in the cassava to diffuse out and dried in air circulated oven at $50{ }^{\circ} \mathrm{C}$ for 24 hours.

Rice, sorghum, Dry doum fruit flakes, Cassava tubers and red kidney bean grains were ground to get homogenous particles using a laboratory mill (Brabender Automat Mill Quandrumat Senior, Germany) and sieved through a 60 mesh. All raw materials packed and stored in a refrigerator $\left(4^{\circ} \mathrm{C}\right)$ until used.

Preparation of composite flour by mixed rice, sorghum, Cassava, Pysllium and red kidney bean were mixed in mixer and dry doum powder addition according to the percent of doum in table (1)

\subsubsection{Baking method}

Six formulas were baked using the straight dough methods (Trejo-González et al., 2014) with some modifications as presented in Table (1). $100 \mathrm{~g}$ wheat flour or composite flour (mixed raw materials), $5 \mathrm{~g}$ sugar, $7 \mathrm{~g}$ shortening, $1.5 \mathrm{~g}$ dry yeast, $1 \mathrm{~g}$ salt and water were added as required. The combined materials were mixed for $4 \mathrm{~min}$, raised for $30 \mathrm{~min}$, punched for $5 \mathrm{~min}$, and raised for another $30 \mathrm{~min}$. The dough was divided, punched again for $5 \mathrm{~min}$, rounded and molded. Then it was placed in baking pans and allowed to rise for $60 \mathrm{~min}$ at $30^{\circ} \mathrm{C}$. Pans bread were baked for $10 \mathrm{~min}$ at $250^{\circ} \mathrm{C}$ then allowed to cool on racks for about $1 \mathrm{hr}$ before evaluation.

Four Pan bread formulae were compared with two controls pan bread samples.

Table 1: Ingredients $\%$ of different formula to prepare pan bread

\begin{tabular}{lccccccc}
\hline Formulae & Wheat & Psyllium & Sorghum & Red kidney bean & Cassava & Rice & Doum \\
\hline Control (1) & 100 & --- & --- & ----- & -- \\
Control (2) & --- & 5 & 10 & 40 & 25 & 20 & - \\
Formula 1 & --- & 5 & 10 & 40 & 20 & 20 & 5 \\
Formula 2 & --- & 5 & 10 & 40 & 15 & 20 & 10 \\
Formula 3 & --- & 5 & 10 & 40 & 5 & 20 & 15 \\
Formula 4 & --- & 5 & 10 & 40 & 20 & 20 \\
\hline
\end{tabular}

Control (1) wheat flour 100\%, Control (2) composite flour without doum, Formula (1) composite flour with 5\% doum, Formula (2) composite flour with 10\% doum, Formula (3) composite flour with $15 \%$ doum, Formula (4) composite flour with $20 \%$ doum

\subsubsection{Chemical composition of raw materials and pan bread samples}

Moisture, crude Protein, total fat, ash and crude fibers were determined in raw materials and tested pan bread according to the method outlined in AOAC (2005). Carbohydrates were calculated by differences as follow:

Total carbohydrates $=100-($ fat + fiber + ash + protein $)$.

\subsubsection{Minerals content of raw materials and pan bread samples:}

Minerals content of samples were determined according to the method outlined in AOAC (2019). Minerals content of sodium $(\mathrm{Na})$, potassium $(\mathrm{K})$, calcium $(\mathrm{Ca})$, magnesium $(\mathrm{Mg})$, iron $(\mathrm{Fe})$ and zinc ( $\mathrm{Zn})$ were digested by Microwave Go Plus (Anton Paar, Austria) then determined using Microwave Plasma-Atomic Emission Spectroscopy (MP-AES 4210, Malaysia).

\subsubsection{Physical characteristics of different formula pan bread samples}

Physical characteristics of the prepared pan bread; weight and volume were determined according to the method described by Colims et al., (1982) and AACC (1995), respectively. Specific volume $\left(\mathrm{cm}^{3} / \mathrm{g}\right)$ was calculated by dividing volume by its weight.

\subsubsection{The texture profile analysis (TPA) of different formula pan bread}

A Texture analyzer (BROOKFIELD CT3 TEXTURE ANALYSER operating instructions Manual No.M08-372-C0113, Stable Micro Systems, USA) was used to measure the Texture profile of 
cakes in terms of hardness $(\mathrm{N})$ Cohesiveness, gumminess $(\mathrm{N})$, chewiness $(\mathrm{mj})$, adhesiveness $(\mathrm{mj})$, springiness $(\mathrm{mm})$, and resilience of the sample. the sample $(2.5 \mathrm{~cm}$ height and $4 \mathrm{~cm}$ diameter $)$ were compressed twice to $40 \%$ of the original height using settings as text-TPA, probe- $36 \mathrm{~mm}$ cylindrical, Pre-text speed $-2 \mathrm{~mm} / \mathrm{s}$, post- text speed $-2 \mathrm{~mm}$. the experiments were conducted under ambient conditions.

\subsubsection{Color analysis of pan bread formulae}

Color of different formulae pan bread was determined in terms of using Lab scan XE spectrocolorimeter (Hunter Associate Laboratory Virginia, USA, and Model LX16244) following the method of McGuire (1992). Pan bread from each batch was placed in a glass sample cup of $5.8 \mathrm{~cm}$ internal diameter and color coordinates were measured. An average of 10 readings was reported for each sample.

\subsubsection{Sensory evaluation of pan bread formulae}

The sensory characteristics of the tested pan bread were evaluated according to Bourré et al., (2019). The different formulae pan bread were cut into quarters and coded with three digit random numbers. Panelist always received the same quarter of the bread slice. Twenty experienced and trained panelists from the staff of Food Technology Institute, Agricultural Research Center were selected to participate in the panel. The pan breads were evaluated for taste, odor, texture, crust color, crumb color, general appearance and overall palatability.

\subsubsection{Statistical analysis}

Statistical analyses were carried out by SPSS 16 program (SPSS, 2000). Data were expressed as means \pm SD. and the Statistical analysis was performed using one-way analysis of variance followed by Duncan's tests.

\section{Results and Discussion}

\subsection{Chemical composition of raw materials}

Beans have two or three folds amounts more of protein than cereals and provide a suitable path for eliminating the protein malnutrition (Shehzad et al., 2015). So, in the current study, it could be noticed that the highest protein content $(26.39 \% \pm 1.23)$ was in the red kidney bean (Table 2$)$. These results are similar to found by Thapa, (2012) who reported that red kidney bean possess an excellent nutritional profile with $22.7 \%$ protein, $3.5 \%$ ash, $1 \%$ fat and $57.7 \%$ carbohydrates. As compared to other starchy foods red kidney beans starch is much slowly digested and possesses a very low glycemic index (Nyau, 2014).

Table 2: Chemical composition (\%) of raw materials

\begin{tabular}{lccccccc}
\hline Constituents & Wheat & Rice & Sorghum & Cassava & $\begin{array}{c}\text { Red kidney } \\
\text { bean }\end{array}$ & Doum & Psyllium \\
\hline Moisture & $11.99 \pm 0.45$ & $9.42 \pm 1.12$ & $10.45 \pm 1.21$ & $11.25 \pm 1.28$ & $12.49 \pm 1.05$ & $11.15 \pm 1.07$ & $11.29 \pm 1.26$ \\
Crude Protein* & $11.85 \pm 0.57$ & $7.71 \pm 0.65$ & $9.85 \pm 1.06$ & $3.09 \pm 0.13$ & $26.39 \pm 1.23$ & $7.65 \pm 0.21$ & $13.30 \pm 0.04$ \\
Fat* & $1.10 \pm 0.36$ & $2.22 \pm 0.10$ & $2.89 \pm 0.10$ & $0.66 \pm 0.29$ & $2.14 \pm 0.27$ & $2.30 \pm 0.10$ & $4.20 \pm 0.24$ \\
Total Ash* & $0.61 \pm 0.28$ & $0.68 \pm 0.39$ & $1.12 \pm 0.02$ & $1.84 \pm 0.05$ & $4.16 \pm 0.38$ & $5.95 \pm 0.20$ & $4.70 \pm 2.57$ \\
Crude Fiber* & $0.66 \pm 0.25$ & $0.25 \pm 0.11$ & $3.31 \pm 0.21$ & $2.25 \pm 0.34$ & $5.49 \pm 0.25$ & $20.42 \pm 0.30$ & $40.33 \pm 4.34$ \\
Total & $85.78 \pm 2.13$ & $89.14 \pm 3.21$ & $82.83 \pm 4.82$ & $92.16 \pm 7.32$ & $61.82 \pm 4.38$ & $63.68 \pm 0.9$ & $37.47 \pm 0.84$ \\
\hline Carbohydsrate* & & & & & &
\end{tabular}

Values are means \pm SD $(n=3)$. * On dry weight basis

Psyllium (table2) had the highest values of fat $(4.20 \% \pm 0.24)$ and fiber $(40.33 \% \pm 4.34)$. Ziemichod et al., (2018) reported that Plantago psyllium contained $4.16 \%$ fat and $74.45 \%$ fiber. The same table showed that the highest value of ash content was in doum powder $(5.95 \% \pm 0.20)$. Seleem, (2015) found that Doum powder had highest level of ash content $(6.60 \%)$ that some other raw materials 
The highest carbohydrates contents Table (2) were in cassava, rice and wheat flours $(92.16$, 89.14 and $85.78 \%$, respectively). Folake et al., (2012) reported that cassava is an excellent energy source (80-90\% carbohydrate) forming an important source of energy in the human diet worldwide. Rice containing no gluten, low levels of sodium, protein, fat and fiber, and a high amount of easily digested carbohydrates is desirable for certain special diet such as gluten-free food products (Ji et al., 2007).

The variation in chemical composition among researchers may be due to different growing conditions (such as geographic, seasonal variations, climatic conditions and soil characteristics), and extent of foreign materials, impurities, varieties, different processing and measuring methods (TaherMaddah et al., 2012).

\subsection{Mineral contents of raw materials}

Red kidney beans were the best source of minerals like $\mathrm{K}, \mathrm{Ca}, \mathrm{Mg}$ and $\mathrm{Fe}$ (Souci et al., 2000). The results in Table 3 showed that red kidney bean recorded the highest contents of calcium, magnesium and zinc $(92.80,123.20$ and $3.74 \mathrm{mg} / 100 \mathrm{~g}$, respectively). Sodium, potassium and iron contents were the highest values in doum powde $(226.24,512.06$ and $5.46 \mathrm{mg} / 100 \mathrm{~g}$, respectively). Aamer (2015) showed that the doum-fruit flour (DFF) could be considered as a good source of minerals $(\mathrm{K}, \mathrm{Ca}, \mathrm{Na}$, and $\mathrm{Mg})$. Potassium, calcium and iron contents of psyllium were similar to doum flour. These results of $\mathrm{Na}, \mathrm{Ca}$ and $\mathrm{Fe}$ contents in doum powder are in line with Seleem (2015) but they were different in other minerals. The variation in results may be due to the difference in planting location and planting time as reported by Ezekwe et al., (1999).

Table 3: Minerals content ( $\mathrm{mg} / 100 \mathrm{~g}$ dry weight) of raw materials

\begin{tabular}{cccccccc}
\hline $\begin{array}{c}\text { Minerals } \\
\text { content }\end{array}$ & Wheat & Rice & Sorghum & Cassava & $\begin{array}{c}\text { Red kidney } \\
\text { bean }\end{array}$ & Doum & Psyllium \\
\hline $\mathbf{N a}$ & $25.89 \pm 0.31$ & $123.00 \pm 0.13$ & $157.20 \pm 1.28$ & $22.23 \pm 0.01$ & $21.82 \pm 1.35$ & $226.2 \pm 5.16$ & $54.62 \pm 2.18$ \\
$\mathbf{K}$ & $140.20 \pm 2.33$ & $185.64 \pm 4.38$ & $192.35 \pm 6.27$ & $12.29 \pm 0.01$ & $342.0 \pm 1.23$ & $512.06 \pm 3.27$ & $411.3 \pm 6.27$ \\
$\mathbf{C a}$ & $12.50 \pm 0.22$ & $32.39 \pm 0.48$ & $20.85 \pm 0.13$ & $13.80 \pm 0.00$ & $92.80 \pm 5.29$ & $34.85 \pm 0.14$ & $34.54 \pm 0.84$ \\
$\mathbf{M g}$ & $119.05 \pm 0.26$ & $120.21 \pm 0.01$ & $35.9 \pm 0.02$ & $20.00 \pm 0.27$ & $123.20 \pm 2.16$ & $70.35 \pm 0.83$ & $51.82 \pm 0.68$ \\
$\mathbf{F e}$ & $0.79 \pm 0.12$ & $0.45 \pm 0.04$ & $0.46 \pm 0.02$ & $0.30 \pm 0.02$ & $5.03 \pm 0.95$ & $5.46 \pm 0.18$ & $2.91 \pm 0.02$ \\
$\mathbf{Z n}$ & $0.50 \pm 0.09$ & $0.23 \pm 0.02$ & $0.27 \pm 0.01$ & $0.22 \pm 0.02$ & $3.74 \pm 0.01$ & $2.87 \pm 0.02$ & $2.73 \pm 0.04$ \\
\hline
\end{tabular}

Values are means $(\mathrm{n}=3) \pm \mathrm{SD}$.

\subsection{Chemical composition of pan bread formula}

Proximate analysis such as protein, fat, ash, crude fiber and total carbohydrates, were determined in different tested pan bread formulae and the results are showed in Table (4). Protein, fat, ash and crude fiber contents were increased in control (1) relative to control (2) by 9.17, 5.79, 130.92 and $533.80 \%$, respectively. Protein, fat, ash and crude fiber contents were also increased from control (2) to formula (4) by $11.84,97.48,36.46$ and $167.11 \%$, respectively.

Table 4: Chemical composition (\% on dry weight basis) of pan bread formulae

\begin{tabular}{lcccccc}
\hline $\begin{array}{l}\text { Chemical Constituents } \\
\text { \% }\end{array}$ & $\begin{array}{c}\text { Control } \\
(\mathbf{1})\end{array}$ & $\begin{array}{c}\text { Control } \\
(\mathbf{2})\end{array}$ & Formula 1 & Formula 2 & Formula 3 & Formula 4 \\
\hline Crude Protein & $11.45 \pm 0.91$ & $12.50 \pm 0.68$ & $12.75 \pm 0.38$ & $13.11 \pm 0.86$ & $13.52 \pm 0.24$ & $14.01 \pm 0.56$ \\
Fat & $2.07 \pm 0.04$ & $2.19 \pm 0.01$ & $2.25 \pm 0.02$ & $2.32 \pm 0.01$ & $2.45 \pm 0.01$ & $2.52 \pm 0.02$ \\
Total Ash & $1.52 \pm 0.02$ & $3.51 \pm 0.02$ & $3.71 \pm 0.03$ & $4.16 \pm 0.03$ & $4.50 \pm 0.03$ & $4.79 \pm 0.04$ \\
Crude fiber & $0.71 \pm 0.03$ & $4.50 \pm 0.07$ & $6.1 \pm 0.07$ & $8.20 \pm 0.11$ & $10.31 \pm 0.12$ & $12.02 \pm 0.13$ \\
Total carbohydrates & $84.25 \pm 3.19$ & $71.30 \pm 4.13$ & $75.19 \pm 3.25$ & $72.21 \pm 4.36$ & $69.22 \pm 3.54$ & $66.66 \pm 3.28$ \\
\hline
\end{tabular}

Values are means $\pm \operatorname{SD}(\mathrm{n}=3)$.

On the other hand, total carbohydrates content decreased from control (1) to control (2) by $15.37 \%$ and from control (2) to formula (4) by $6.50 \%$. Doum-fruit powder up to $20 \%$ in this study increased the nutritional value of formulae in terms of fiber, protein, and ash contents. Doum-fruit 
flour up to $15 \%$ could partially substitute the wheat flour in bread to increase its nutritional value in terms of fiber content (Aboshora et al., 2015).

\subsection{Minerals content of pan bread formulae:}

It is well known elsewhere that a doum fruit is a rich source of minerals such as $\mathrm{Na}, \mathrm{K}$ and $\mathrm{Ca}$ (Aboshora et al., 2014; Admassu et al., 2013). The present results showed a considerable significant difference $(\mathrm{p} \leq 0.05)$ in all the mineral elements in the pan bread formulae (Table 5). It could be noted that increase of doum powder levels to the formulation significantly $(\mathrm{P} \leq 0.05)$ increased $\mathrm{K}, \mathrm{Ca}, \mathrm{Na}$, $\mathrm{Mg}, \mathrm{Fe}$ and $\mathrm{Zn}$ content of pan bread formulae compared to that wheat of control. In view to this study, the ratio of sodium to potassium in the all pan bread formulae was in agreement with the work of Aremu et al., (2006) who reported that the $\mathrm{Na} / \mathrm{K}$ ratio less than one has a great importance in the human body for the control of the high blood pressure.

These breads were found to be rich sources of essential minerals which in most instances exceed the recommended dietary allowance (RDA), thus may keep the balances and ratios between those in need (Aboshora et al., 2015).

Table 5: Minerals content (mg/100g) of pan bread formulae

\begin{tabular}{lllllll}
\hline $\begin{array}{l}\text { Minerals } \\
\text { content }\end{array}$ & Control (1) & Control (2) & Formula 1 & Formula 2 & Formula 3 & Formula 4 \\
\hline $\mathbf{N a}$ & $205.80 \pm 0.43$ & $222.90 \pm 0.23$ & $242.33 \pm 0.64$ & $263.22 \pm 0.94$ & $273.85 \pm 0.39$ & $279.50 \pm 0.31$ \\
$\mathbf{K}$ & $150.21 \pm 8.26$ & $313.7 \pm 15.26$ & $359.9 \pm 12.29$ & $441.3 \pm 19.25$ & $476.6 \pm 15.29$ & $511.8 \pm 14.96$ \\
$\mathbf{C a}$ & $18.25 \pm 0.18$ & $52.80 \pm 0.27$ & $54.22 \pm 0.12$ & $56.01 \pm 0.36$ & $57.26 \pm 0.61$ & $60.06 \pm 0.43$ \\
$\mathbf{M g}$ & $112.94 \pm 0.11$ & $120.59 \pm 0.16$ & $128.93 \pm 0.64$ & $132.24 \pm 0.34$ & $134.9 \pm 0.38$ & $138.75 \pm 0.32$ \\
$\mathbf{F e}$ & $0.75 \pm 0.08$ & $2.64 \pm 0.11$ & $3.00 \pm 0.05$ & $3.33 \pm 0.27$ & $3.60 \pm 0.23$ & $3.89 \pm 0.18$ \\
$\mathbf{Z n}$ & $0.48 \pm 0.04$ & $1.63 \pm 0.02$ & $1.70 \pm 0.08$ & $1.86 \pm 0.08$ & $1.95 \pm 0.05$ & $2.01 \pm 0.05$ \\
\hline
\end{tabular}

Values are means \pm SD $(\mathrm{n}=3)$.

\subsection{Physical properties of pan bread formulae}

Weight, volume and specific volume of pan bread formulae were evaluated and the results are showed in Table (6). From the results, it could be indicated that the weight, volume and specific volume of control (1) were $148 \mathrm{~g}, 600 \mathrm{~cm}^{3}$ and $4.05 \mathrm{~cm}^{3} / \mathrm{g}$ respectively. It was also observed that weight values increased from $150 \mathrm{~g}$ in the control (2) to $157 \mathrm{~g}$ in the formula (4) doum. Whilst, the volume and specific volume were decreased from $593 \mathrm{~cm}^{3}$ and $3.95 \mathrm{~cm}^{3} / \mathrm{g}$ to $577 \mathrm{~cm}^{3}$ and $3.68 \mathrm{~cm}^{3} / \mathrm{g}$, respectively.

The reduction in loaf volume seems to be related to the high amount of fiber present in the doum fruit flour, which diluted the gelling properties of psyllium formation during fermentation and baking. Moreover, the resulting gluten with fiber addition became stiffer and less extensible, and this led to a lower ability of the dough to retain the gas (Wang et al., 2004). These results agreed with the findings of Aboshora et al., (2015) who reported that, the specific volume of bread with doum flour is supposed to be within the range of $3.22-4.87 \mathrm{~cm}^{3} / \mathrm{g}$. The specific volume of standard bread should be $6 \mathrm{~cm}^{3} / \mathrm{g}$ and should not be less than $3.5 \mathrm{~cm}^{3} / \mathrm{g}$ (CGPRDI, 1983).

Table 6: Physical properties of pan bread formulae

\begin{tabular}{lccc}
\hline Pan bread formulae & $\begin{array}{c}\text { Weight } \\
(\mathbf{g})\end{array}$ & $\begin{array}{c}\text { Volume } \\
\left(\mathbf{c m}^{\mathbf{3}}\right)\end{array}$ & $\begin{array}{c}\text { Specific volume } \\
\left(\mathbf{c m}^{3} / \mathbf{g}\right)\end{array}$ \\
\hline Control (1) & $148^{\mathrm{c}}$ & $600^{\mathrm{a}}$ & $4.05^{\mathrm{a}}$ \\
Control (2) & $150^{\mathrm{b}}$ & $593^{\mathrm{b}}$ & $3.95^{\mathrm{ab}}$ \\
Formula (1) & $151^{\mathrm{ab}}$ & $589^{\mathrm{bc}}$ & $3.90^{\mathrm{b}}$ \\
Formula (2) & $153^{\mathrm{ab}}$ & $584^{\mathrm{bc}}$ & $3.82^{\mathrm{bc}}$ \\
Formula (3) & $155^{\mathrm{ab}}$ & $581^{\mathrm{c}}$ & $3.75^{\mathrm{c}}$ \\
Formula (4) & $157^{\mathrm{a}}$ & $577^{\mathrm{d}}$ & $3.68^{\mathrm{d}}$ \\
\hline
\end{tabular}

Means followed by different letters in the same column are significantly different $(\mathrm{P} \leq 0.05)$ 


\subsection{Texture profile analysis of pan bread formulae}

The results in Table (7) showed the effect of doum incorporated on pan bread texture profile analysis. It was observed that increasing of doum flour levels in the pan bread formulae increased hardness and chewiness. On the other hand, resilience, cohesiveness and springiness were decreased with increasing of doum flour levels in the pan bread formulae

Hardness increased from $1.11 \mathrm{~N}$ for wheat control and $1.30 \mathrm{~N}$ for formula control to $2.84 \mathrm{~N}$ for formula with $20 \%$ doum flour, and it was directly proportional to the amount of doum added; this may be as a result high fiber content in the pan bread incorporated with doum flour. The firmness of the product depends on the resilience value, whenever was small can recover faster from deformation (Bhol and Bosco, 2014). The results were revealed that the pan bread sample with $20 \%$ doum was harder than the other pan bread samples.

Table 7: Texture profile analysis of pan bread formulae

\begin{tabular}{lccccc}
\hline Formulae & Hardness (N) & Resilience & Cohesiveness & Springiness (mm) & Chewiness (mj) \\
\hline Control (1) & $1.11^{\mathrm{e}}$ & $0.65^{\mathrm{a}}$ & $1.24^{\mathrm{a}}$ & $4.17^{\mathrm{a}}$ & $4.10^{\mathrm{e}}$ \\
Control (2) & $1.30^{\mathrm{d}}$ & $0.53^{\mathrm{b}}$ & $0.95^{\mathrm{b}}$ & $3.88^{\mathrm{ab}}$ & $5.56^{\mathrm{d}}$ \\
Formula 1 & $1.36^{\mathrm{d}}$ & $0.50^{\mathrm{b}}$ & $0.92^{\mathrm{b}}$ & $3.76^{\mathrm{b}}$ & $6.14^{\mathrm{c}}$ \\
Formula 2 & $1.45^{\mathrm{c}}$ & $0.47^{\mathrm{b}}$ & $0.86^{\mathrm{c}}$ & $3.68^{\mathrm{c}}$ & $6.72^{\mathrm{c}}$ \\
Formula 3 & $1.61^{\mathrm{b}}$ & $0.46^{\mathrm{b}}$ & $0.80^{\mathrm{c}}$ & $3.59^{\mathrm{d}}$ & $7.40^{\mathrm{b}}$ \\
Formula 4 & $2.84^{\mathrm{a}}$ & $0.44^{\mathrm{c}}$ & $0.75^{\mathrm{d}}$ & $3.56^{\mathrm{d}}$ & $8.25^{\mathrm{a}}$ \\
\hline
\end{tabular}

Means followed by different letters in the same row, significantly different $(\mathrm{P} \leq 0.05)$

Chewiness was increased as the amount of doum flour increased from $4.10 \mathrm{mj}$ (wheat control) and $5.56 \mathrm{mj}$ in formula control to $8.25 \mathrm{mj}$ in formula contained $20 \%$ doum. Meanwhile, resilience, cohesiveness and springiness were decreased from $0.65,1.24$ and $4.17 \mathrm{~mm}$ in wheat control and 0.53 , 0.95 and $3.88 \mathrm{~mm}$ in formula control to $0.44,0.75$ and $3.56 \mathrm{~mm}$ in formula contained $20 \%$ doum, respectively. Starches play an important role in pan bread baking processes during pan bread baking, starch granules gelatinize and have the ability to trap air bubbles, facilitating gas retention during fermentation (Hug-Iten et al., 2001). Rice and maize flours, along with various techniques or additives have also been applied to improve physicochemical properties, acceptance, and shelf life of dough and bread (Therdthai et al., 2016).

\subsection{Color analysis of pan bread formulae}

The $L^{*}, a^{*}$ and $b^{*}$ values of pan bread formulae have been presented in Table (8). The tested pan bread formulae were significantly darker with lower $L^{*}$ values compared to the wheat control and formula control. Pan bread made from wheat flour (72\% extraction) and formula control free doum displayed a higher lightness $L^{*}$, and $b^{*}$ values and lower $a^{*}$ values as compared to the other formulae, may be because of the brown color of the doum. The brown color of pan bread is the result of millard reaction occurring between reducing sugars and amino acids during baking process, as well as time and temperature of baking (Cauvain, 2016).

Table 8: Color analysis of pan bread formulae

\begin{tabular}{lccc}
\hline Pan bread formulae & $\boldsymbol{L}^{*}$ & $\boldsymbol{a}^{\boldsymbol{*}}$ & $\boldsymbol{b}^{*}$ \\
\hline Control (1) & $79.5^{\mathrm{a}}$ & $1.9^{\mathrm{e}}$ & $35.4^{\mathrm{a}}$ \\
Control (2) & $70.4^{\mathrm{b}}$ & $2.6^{\mathrm{d}}$ & $30.5^{\mathrm{b}}$ \\
Formula (1) & $63.1^{\mathrm{c}}$ & $3.1^{\mathrm{c}}$ & $32.7^{\mathrm{b}}$ \\
Formula (2) & $61.9^{\mathrm{c}}$ & $3.5^{\mathrm{c}}$ & $27.3^{\mathrm{c}}$ \\
Formula(3) & $56.6^{\mathrm{d}}$ & $4.2^{\mathrm{b}}$ & $24.1^{\mathrm{c}}$ \\
Formula (4) & $51.8^{\mathrm{e}}$ & $5.1^{\mathrm{a}}$ & $20.3^{\mathrm{d}}$ \\
\hline
\end{tabular}

Means followed by different letters in the same Colum significantly different $(\mathrm{P} \leq 0.05)$.

In case of 15 and $20 \%$ doum, which are of dark brown color, caused significantly lower $L^{*}$, higher $a^{*}$ and $b^{*}$ values. These may be attributed high protein content which is known to have negative correlation with $L^{*}$ value (Mamat et al., 2010). Darkness in both crust and crumb could be related to the lysine content (Admassu et al., 2013). 


\subsection{Sensory properties of pan bread formulae}

Sensory evaluation is one aspect of greatest importance since consumer acceptance usually encourages the marketing process of any new product. Results in Table (9) showed the sensory properties score of free gluten pan bread formula. The pan bread prepared from wheat flour control (1) gives the highest scores of all sensory properties for panelists. There were no significant $(\mathrm{P}<0.05)$ differences among formula control, formula (1) and (2) doum powder in taste and odor. But there were no significant differences between formula control and formula (1) doum powder for texture, crust color, crumb color and general appearance. Mohammed et al., (2012), reported that the darkening of crust and crumb might have been attributed to the Maillard reaction during baking due to higher lysine content. Darkness in both crust and crumb could be related to the lysine content (Admassu et al., 2013).

Sensory evaluation showed that free gluten pan bread supplemented of doum powder $5 \%$ were nearly acceptable by panelists with formula control (2). On the other hand (Aboshora et al., 2015) reported wheat flour pan breads supplemented up to $15 \%$ doum powder flour were acceptable to the panelists and there was no significant difference in terms of taste, texture and overall acceptability compared to the control.

Table 9: Sensory properties of pan bread formulae

\begin{tabular}{|c|c|c|c|c|c|c|c|}
\hline Formulae & $\begin{array}{c}\text { Taste } \\
20\end{array}$ & $\begin{array}{c}\text { Odor } \\
\mathbf{2 0}\end{array}$ & $\begin{array}{c}\text { Texture } \\
15\end{array}$ & $\begin{array}{c}\text { Crust } \\
\text { color } \\
15 \\
\end{array}$ & $\begin{array}{c}\text { Crumb } \\
\text { color } \\
15 \\
\end{array}$ & $\begin{array}{c}\text { General } \\
\text { appearance } \\
15 \\
\end{array}$ & $\begin{array}{c}\text { Overall } \\
\text { acceptability } \\
(\mathbf{1 0 0})\end{array}$ \\
\hline Control (1) & $19.25^{\mathrm{a}}$ & $19.0^{\mathrm{a}}$ & $14.38^{\mathrm{a}}$ & $14.0^{\mathrm{a}}$ & $14.0^{\mathrm{a}}$ & $14.0^{\mathrm{a}}$ & $94.63^{\mathrm{a}}$ \\
\hline Control (2) & $17.94^{b}$ & $18.00^{\mathrm{b}}$ & $14.00^{\mathrm{a}}$ & $13.74^{\mathrm{ab}}$ & $13.12^{b}$ & $13.27^{\mathrm{b}}$ & $90.07^{\mathrm{b}}$ \\
\hline Formula 1 & $17.49^{b}$ & $17.94^{b}$ & $13.56^{\mathrm{ab}}$ & $13.00^{\mathrm{b}}$ & $12.74^{\mathrm{b}}$ & $13 . .00^{\mathrm{b}}$ & $87.73^{b}$ \\
\hline Formula 2 & $17.00^{b c}$ & $17.00^{b c}$ & $13.00^{\mathrm{b}}$ & $12.51^{\mathrm{c}}$ & $12.18^{\mathrm{c}}$ & $12.34^{\mathrm{c}}$ & $84.03^{b c}$ \\
\hline Formula 3 & $16.40^{\mathrm{c}}$ & $16.15^{\mathrm{c}}$ & $12.21^{b c}$ & $12.00^{\mathrm{c}}$ & $12.00^{\mathrm{c}}$ & $11.74^{\mathrm{d}}$ & $80.50^{c}$ \\
\hline formula 4 & $15.10^{d}$ & $15.00^{d}$ & $11.35^{\mathrm{c}}$ & $11.89^{\mathrm{d}}$ & $11.52^{\mathrm{d}}$ & $10.40^{\mathrm{e}}$ & $75.26^{\mathrm{d}}$ \\
\hline
\end{tabular}

Means followed by different letters in the same row, significantly different $(\mathrm{P} \leq 0.05)$

\subsection{Percentages of the recommended dietary allowances (\% RDA) provided from Doum pan bread for Children (4-8 years).}

The percentages of the recommended dietary allowances (\% RDA) are provided from 100g of pan bread for children are shown in Table 10), it could be observed that formulae of pan bread with $15 \%$ doum powder covers up to $71.16 \%$ of protein requirement, $36.00 \%$ of iron requirement, $38.40 \%$ of zinc and $5.73 \%$ of calcium. It could be noticed that consuming doum powder pan bread could provide children with part of their daily requirements of protein, fiber, calcium, iron and zinc.

Table 10: Amounts of the tested doum pan bread samples which should be intake to gain the children (4-8 years) RDA of some nutrients.

\begin{tabular}{lcccccc}
\hline & \multicolumn{5}{c}{ Amount (gm) } \\
\cline { 2 - 7 } RDA of some nutrients & Control & Control & \multicolumn{4}{c}{ Doum } \\
\cline { 4 - 7 } & $\mathbf{( 1 )}$ & $\mathbf{( 2 )}$ & Formula 1 & Formula 2 & Formula 3 & Formula 4 \\
\hline Protein (19 g/d) & 60.26 & 65.78 & 67.11 & 69.00 & 71.16 & 73.73 \\
Fiber (25 g/d) & 2.84 & 18.00 & 24.4 & 32.8 & 41.24 & 48.08 \\
Calcium (1000 mg/d) & 1.83 & 5.28 & 5.42 & 5.60 & 5.73 & 6.01 \\
Iron (10 mg/d) & 7.5 & 26.4 & 30.00 & 33.30 & 36.00 & 38.9 \\
Zinc (5 mg/d) & 9.60 & 32.60 & 34.00 & 37.20 & 38.40 & 40.20 \\
\hline
\end{tabular}

According to Food and Nutrition Board, Institute of Medicine, \&National Academies, (2004).

\section{Conclusion}

From the above results, it could be concluded that the free gluten pan bread formulae incorporated with doum flour up to $10 \%$ was acceptable and provided a high nutritional value while $15 \%$ was high nutritional value with only a small depreciation in pan bread quality. 


\section{References}

AACC, 1995. Approved Methods of AACC. Ninth ed. The American Association of Cereal Chemists, Saint Paul, Minnesota.

Aamer, R.A., 2015. Physicohemical Properties of Doum (Hyphaene thebaica) Fruits and Utilization of its Flour in Formulating Some Functional Foods. Alex. J. Food. Sci. \& Technol., 12(2): 2939.

Abdel-Rahman, N., 2011. A study of some Sudanese Edible Forest Fruits and Their Nectars. Ph.D, Thesis in Food technology to Sudan Academy of Sciences. Khartoum, Sudan.

Aboshora, W., Z. Lianfu , M. Dahir, M.A. Gasmalla, A. Musa, E. Omer, and M. Thapa, 2014. Physicochemical, nutritional and functional properties of the epicarp, flesh and pitted sample of doum fruit (Hyphaene Thebaica L). J Food Nutr. Res., 2(4):180-186.

Aboshora, W., Z. Lianfu, M. Dahir, M. Qingran, S. Qingrui, L. Jing, and A. Omer, 2015. Influence of doum (Hyphaene thebaica L.) flour addition on dough mixing properties, bread quality and antioxidant potential. Journal of Food Science and Technology, 53(1): $591-600$.

Aboshora, W., M. Abdalla, F.F. Niu, J.H. Yu, H. Raza, S.E. Idriss, N.Q.M. Al-Haj, A. Al-Farga, and Z. Lianfu, 2017. "Compositional and structural analysis of epicarp, flesh and pitted sample of Doum fruit (Hyphaene thebaica L.). International Food Research Journal , 24(2): 650-656.

Admassu, M., A. Bekele, and J.C. Kim, 2013. Nutritional composition of Balanites aegyptiaca (desert date) and Hyphaene thebaica (doum palm) fruits consumed by Hamadryas Baboons (Papio hamadryas hamadryas) in Awash National Park, Ethiopia. J Nutr Ecol Food Res., 1(3):198206.

Aremu, M.O., O. Olaofe and T.E. Akintayo, 2006. A comparative study on the chemical and amino acid composition of some Nigerian underutilized legume flours. Pak. J Nutr, 5(1):34-38.

Aristizábal, J., J.A. García, and B. Ospina, 2017. Refined cassava flour in bread making: a review Ingeniería e Investigación, 37 (1): 25-33.

Anjali, V. and M. Renu 2015. Psyllium (Plantago ovata) Husk: A Wonder Food for Good Health. International Journal of Science and Research, 4 (9): 1581-1585.

AOAC, 2005. Association of Official of Analytical Chemists Official Methods of Analysis. $18^{\text {th }}$ Ed., Pub. By the AOAC, Arlington, Virginia, 2220 USA.

AOAC, 2019. AOAC Official Method 2015.01 Heavy Metals in Food. Inductively Coupled PlasmaMass Spectrometry First Action 2015.

Bayad, A.E. 2016. Influences of doum fruit (Hyphaene thebaica) extract on the reproductive parameters, blood picture, lipid profile and hepato-renal functions in rats. Merit Research Journal of Medicine and Medical Sciences, 4(8): 384-391.

Belorio, M. and M. Gómez, 2020. Effect of Hydration on Gluten-Free Breads Made with Hydroxypropyl Methylcellulose in Comparison with Psyllium and Xanthan Gum. Foods, 9, 1548: 1 -10.

Belorio, M., G. Marcondes, and M. Goméz, 2020. Influence of psyllium versus xanthan gum in starch properties. Food Hydrocoll, 105: 105843

Bhol, S. and S.J.D. Bosco, 2014 Influence of malted finger millet and red kidney bean flour on quality characteristics of developed bread. LWT Food Sci., Technol., 55(1):294-300.

Bourne, M.C., 2003. Food texture and viscosity: Concept and measurement. Elsevier Press, New York/ London.

Bourré, L., P. Frohlich, G. Young, Y. Borsuk, E. Sopiwnyk, A. Sarkar, W.T. Nickerson, A. Yongfeng, A. Dyck, and L. Malcolmson, 2019. Influence of particle size on flour and baking properties of yellow pea, navy bean, and red lentil flours, Cereal Chemist, 96:655-667.

Boye, J.I., F. Zare, and A. Pletch, 2010. Pulse proteins: processing, characterization, functional properties and applications in food and feed. Food Res. Int., 43:414- 431.

Cauvain, S.P., 2016. "Bread and other bakery products", The Stability and Shelf Life of Food, Woodhead Publishing, Elsevier,USA, $2^{\text {nd }}$ ed., 431-459.

CGPRDI, 1983. Bread making, China Grain Products Research and Development Institute Taipei, Taiwan, 23.

Colims, J.L., S.M. Ralantari, and A.R. Post, 1982. Peanut hull flour as dietary fiber in wheat bread. J. Food Sci., 47:1899. 
Dykes, L. and L.W. Rooney, 2007. Phenolic compounds in cereal grains and their health benefits. Cereal Foods World, 52(3):105-111.

Ezekwe, M.O., T.R. Omara-Alwala, and T. Membrahtu, 1999.Nutritive characterization of purslane accessions as influenced by planting date. Plant Foods for Human Nutrition, 54:183-191.

Folake, O.S., O.O. Bolanle, and A. Titilope, 2012. Nutrient and Anti-Nutrient Content of Soy-Enriched Tapioca. Food and Nutrition Sciences, (3): 784-789.

Food and nutrition board, institute of medicine-national academy of sciences dietary reference intakes, 2004. Recommended Intakes for Individuals.

Haque, A., R.K. Richardson, E.R. Morris, and I.C.M. Dea, 1993. Xanthan-like "weak gel" rheology from dispersions of ispaghula seed husk. Carbohydr. Polym., 22: 223-232.

Hug-Iten, S., F. Echer, and B. Conde-Petit, 2001. Structural properties of starch in bread and bread model systems: influence of an antistaling $\alpha$-amylose. Cereal Chemistry, 78(4): 421-428.

Ji, Y., K. Zhu, H. Qian, and H. Zhou, 2007. Staling of cake prepared from rice flour and sticky rice flour. Food Chemistry, 104: 53-58

Lamacchia, C., A. Camarca, S. Picascia, A. Di Luccia, and C. Ginafrani, 2014. Cereal based gluten free food: How to reconcile nutritional and technological properties of wheat proteins with safety for celiac disease patients. Nutrients, 6:575-590.

Mamat, H., M.O.A. Hardan, and S.E. Hill, 2010. Physicochemical properties of commercial semisweet cookie. Food Chemistry, 121(4): 1029-1038.

Matos, M., T. Sanz , and C. Rosell, 2014. Establishing the function of proteins on the rheological and quality properties of rice based gluten free muffins. Food Hydrocolloids, 35:150-158.

McGuire, R.G., 1992. Reporting of objective color measurements, Horticultural Science, 27: 12541255.

McWatters, K.H., 1985. Functionally of cowpea meal and flour in selected food. In. S.R. Singh \& K.O. Rachie (Eds), Cowpea research production and utilization (pp.361-366). Chlchester. John Wiley \& sons.

Mohammed I., A.R. Ahmed and B. Senge, 2012. Dough rheology and bread quality of wheatchickpea flour blends. Ind. Crop Prod., 36(1):196-202

Nyau, V., 2014. Nutraceutical perspective and utilization of common beans (Phaseolus vulgaris L): A review. Afr. J. Food Agri. Nutr. Deve. 14: 9483-9493.

Phimolsiripol, Y., A. Mukprasirt, and R. Schoenlechner, 2012. Quality Improvement of Rice Based Gluten Free Bread Using Different Dietary Fiber Fractions of Rice Bran., Journal of Cereal Science,56: 389-395.

Sa'adah, N.N., K.I. Purwani, A.P.D. Nurhayati, and N.M. Ashuri, 2017. Analysis of lipid profile and atherogenic index in hyperlipidemic rat (Rattus norvegicus Berkenhout, 1769) that given the methanolic extract of Parijoto (Medinilla speciosa). AIP Conference Proceedings 1854, 020031 (2017); https://doi.org/10.1063/1.4985422

Saturni, L., G. Ferretti, and T. Bacchetti, 2010. The Gluten-Free Diet: Safety and Nutritional Quality Nutrients, 2: 16-34.

Seleem, H.A. 2015. Effect of Blending Doum (Hyphaene thebaica) Powder with Wheat Flour on the Nutritional Value and Quality of Cake. Food and Nutrition Sciences, 6, 622-632.

Souci, S.W., W. Fachmann, and H. Kraut, 2000. Food Composition and Nutrition Tables. Stuttgart: Medpharm Scientific Publishers.

SPSS, 2000. Statistical package for Social Sciences. SPSS for Windows, Version 10, SPSS Inc., Chicago, IL, USA.

Taher-Maddah, M., N. Maheri-Sis, R. Salamatdoustnobar, and A. Ahmadzadeh, 2012. Comparing nutritive value of ensiled and dried pomegranate peels for ruminants using in vitro gas production technique. Annals of Biological Research, 3 (4):1942-1946.

Thapa, N., 2012. Effect of tempering and other processing treatments on the antinutritional factors and a canning quality attribute of dark red kidney beans. M.Sc. Thesis. Uni. Wisc. United States, Dept Food and Nutrition.

Therdthai, N., T. Tanvarakom, P. Ritthiruangdej, and W. Zhou, 2016. Effect of microwave assisted baking on quality of rice flour bread. Journal of Food Quality, 39(4):245-254. http://dx.doi.org/10.1111/ jfq.12207. 
Tewe, O.O., 1983. Thyroid cassava toxicity in animals. In Proc. International workshop on cassava toxicity and thyroid. In: F. Delange, R. 0Canada. IDRC-207e, $114-118$.

Trejo-González, A.S., A.G. Loyo-González, and M.R. Munguía-Mazariegos, 2014. Evaluation of bread made from composite wheat-sweet potato flours. International Food Research Journal, 21(4): 1683-1688.

Wang, M., T. van Vliet, and R.J. Hamer 2004: How gluten properties are affected by pentosans. J. Cereal Sci., 39(3):395-402.

Zandonadi, R., R. Botelho, and W. Araújo, 2009. Psyllium as a Substitute for Gluten in Bread. J. Am Diet Assoc., 109: 1781 - 1784.

Ziemichod, A., M. WÓjcik, and R. RÓzylo, 2018. Seeds of Plantago Psyllium and Plantago Ovate: Minerals composition, grinding and use for gluten-free bread as substitutes for hydrocolloids. Journal of food process Engineering, 42 (1): 1-9. 